\title{
a7 nAChR mediated Fas demethylation contributes to prenatal nicotine exposure-induced programmed thymocyte apoptosis in mice
}

\author{
Han-Xiao Liu ${ }^{1}$, Sha Liu', Wen Qu ${ }^{1}$, Hui-Yi Yan ${ }^{1}$, Xiao Wen ${ }^{1}$, Ting Chen ${ }^{1}$, Li-Fang \\ Hou $^{1}$ and Jie Ping ${ }^{1}$ \\ ${ }^{1}$ Department of Pharmacology, Wuhan University School of Basic Medical Sciences, Wuhan 430071, China
}

Correspondence to: Jie Ping, email: pingjie@whu.edu.cn

Keywords: prenatal nicotine exposure, a7 nAChR, thymocyte apoptosis, TET2, Fas promoter demethylation

Received: July 03, 2017 Accepted: September 20, $2017 \quad$ Published: October 05, 2017

Copyright: Liu et al. This is an open-access article distributed under the terms of the Creative Commons Attribution License 3.0 (CC BY 3.0 ), which permits unrestricted use, distribution, and reproduction in any medium, provided the original author and source are credited.

\section{ABSTRACT}

This study aimed to investigate the effects of prenatal nicotine exposure (PNE) on thymocyte apoptosis and postnatal immune impairments in vivo and further explore the epigenetic mechanisms of the pro-apoptotic effect of nicotine in vitro. The results showed that PNE caused immune impairments in offspring on postnatal day 49, manifested as increased IL-4 production and an increased IgG1/IgG2a ratio in serum. Enhanced apoptosis of total and CD4+SP thymocytes was observed both in fetus and in offspring. Further, by exposing thymocytes to 0-100 $\mu \mathrm{M}$ of nicotine in vitro for $48 \mathrm{~h}$, we found that nicotine increased a7 nicotinic acetylcholine receptor ( $\mathrm{nAChR}$ ) expression, activated the Fas apoptotic pathway, and promoted thymocyte apoptosis in concentration-dependent manners. In addition, nicotine could induce Tet methylcytosine dioxygenase (TET) 2 expression and Fas promoter demethylation, which can be abolished by TET2 siRNA transfection. Moreover, the a7 nAChR specific antagonist a-bungarotoxin can abrogate nicotine-induced TET2 increase, and the following Fas demethylation and Fas-mediated apoptosis. In conclusion, our findings showed, for the first time, that a7 nAChR activation could induce TET2-mediated Fas demethylation in thymocytes and results in the upregulation of Fas apoptotic pathway, which provide evidence for elucidating the PNE-induced programmed thymocyte apoptosis.

\section{INTRODUCTION}

Inflammatory and immune diseases have become an important and ever growing health problem over the past decades [1]. Increasing evidence has identified risks for immune diseases are, to a certain extent, determined by the prenatal adverse environment, causing programed functional alteration of the immune system [2-4]. Normal development of thymocytes in fetus is essential for the establishment of postnatal immune function [5]. Prenatal exposure to xenobiotics could interfere with the normal developmental programming of thymocyte $[3,5]$. During the development process, the thymocytes can be divided into several subpopulations based on the expression of CD4 and CD8: CD4 ${ }^{-} \mathrm{CD}^{-}$double negative cells (DN), $\mathrm{CD}^{+} \mathrm{CD}^{+}$double positive cells (DP) and single positive cells (SP, $\mathrm{CD}^{+} \mathrm{SP}$ or $\mathrm{CD}^{+} \mathrm{SP}$ ). All of these subpopulations express the Fas receptor, which can induce cell apoptosis through death-inducing signaling complex assembly and later the activation of the caspase- 8 . Caspase- 8 then directly activates other members of the caspase family, among which caspase- 3 plays a central role in the final execution-phase of thymocyte apoptosis [6, 7]. It is believed that this Fas/caspase-mediated apoptosis is crucial for regulating thymocyte development [6]. In addition, some reports have suggested that the enhanced apoptosis of fetal thymocytes might persist into postnatal life and, consequently, might cause immune impairments and enhance the risk of immune diseases $[5,8]$.

Cigarette smoke can cause many health problems; however, 25-29\% of pregnant women insist on smoking and approximately half of pregnant women are exposed to 
second-hand smoke $[9,10]$. Of women who smoked during the last 3 months of pregnancy, $48 \%$ reported smoking more than 6 cigarettes per day (data from Pregnancy Risk Assessment Monitoring System). Epidemiological investigations have shown that cigarette smoke exposure during pregnancy is a significant threat to fetal thymocyte development [11]. Experimental studies further demonstrated that prenatal cigarette smoke exposure could promote thymocyte apoptosis permanently [12]. Among all smoke products, nicotine is widely accepted as one of the aversive components that perturb fetal development because nicotine can quickly pass the placental barrier to reach the embryo and accumulate in fetal circulation $[13,14]$. In addition, nicotine was reported as one of the leading candidates of cigarettes for influencing apoptotic processes of immune cells, and the thymus is one of the toxic target organs of nicotine $[15,16]$. However, to date, little is known about whether and how nicotine contributes to the effects of pregnant smoke exposure on fetal thymus apoptosis and postnatal immune function.

Nicotine induces its actions by selectively binding to its receptors known as the nicotinic acetylcholine receptors (nAChRs) [17]. Studies have shown that immune cells express the $\alpha 7 \mathrm{nAChR}$. Although no studies have reported that $\alpha 7 \mathrm{nAChR}$ can induce Fas-mediated apoptosis in thymocytes, considerable evidence has suggested that $\alpha 7 \mathrm{nAChR}$ could directly induce apoptotic pathways in multiple organs [17]. The $\alpha 7 \mathrm{nAChR}$ activation could trigger the influx of extracellular $\mathrm{Ca}^{+}$, which is associated with the upregulated Fas expression [18]. In addition, in a prenatal cigarette smoke exposure model, researchers reported that $\alpha 7 \mathrm{nAChR}$ was activated and the increase of $\alpha 7 \mathrm{nAChR}$ was consistent with the increased caspase expression and apoptosis ratio [19]. Therefore, we speculated that the $\alpha 7 \mathrm{nAChR}$ might exert the pro-apoptotic effects of nicotine on thymocytes by upregulating the Fas expression and the Fas apoptotic pathway.

Extensive data from both human and animal studies indicate that a prenatal altered intrauterine environment during the most important phases of fetal organ development can potentially induce permanent changes in gene expression [20]. Firm evidence has shown that these changes in gene expression are mediated through epigenetic mechanisms [21]. It is clear that the Fas expression is activated by DNA demethylation modification in the Fas promoter at the level of transcription [22]. Moreover, perinatal distress has been reported to increase the DNA demethylation modification of Fas and alter Fas expression permanently, resulting in exceeding apoptosis in many physiological processes in the offspring [23]. The results from our previous studies and other labs demonstrated that nicotine is one of the representative modulators of DNA methylation and could induce abnormal methylation modifications in multiple genes [24-27]. However, whether nicotine could disturb the normal DNA methylation level of Fas and consequently contribute to upregulated Fas expression has not yet been reported and warrants further investigation.

In the present study, we investigated the prenatal nicotine exposure (PNE)-induced programmed thymocyte apoptosis in fetuses and female offspring, and analyzed the changes of immune responses following antigen challenge in PNE offspring. To study the direct effects and molecular mechanisms of nicotine on thymocyte apoptosis, thymocytes were treated with nicotine in vitro. The upregulation of the Fas apoptotic pathway and the Tet methylcytosine dioxygenase (TET) 2-mediated demethylation of the Fas promoter were observed. Further, by using the $\alpha 7 \mathrm{nAChR}$ specific antagonist $\alpha$-bungarotoxin and TET2 siRNA, we reported, for the first time, that $\alpha 7$ nAChR activation could increase Fas expression and the Fas apoptotic pathway through TET2-mediated DNA demethylation in thymocytes. This work will help to characterize the developmental toxicity of nicotine on the fetal thymus and provide evidence for the underlying mechanisms for the developmental origin of immune diseases.

\section{RESULTS}

\section{In vivo}

PNE increased the ratio of immunoglobulin (Ig) G1/ IgG2 and the concentration of interleukin (IL)-4 in serum

Prenatal exposure to cigarette smoke could cause abnormal IL-4 and Ig production during inflammation development in offspring [28]. To investigate the inflammatory responses of PNE offspring, we immunized the offspring with Streptococcus pneumoniae vaccine $(S$. pneumoniae) on postnatal day (PND) 42 and detected the serum contents of IL-4, IgG1 and IgG2a on PND 49. As shown in Figure 1A and 1B, increased the levels of serum $\operatorname{IgG} 1$ before and after immunization and decreased the level of serum $\operatorname{IgG} 2 \mathrm{a}$ before immunization were observed in female PNE offspring compared to the control $(P<0.01, P<0.05, P=0.057)$. As a result, all of the PNE offspring (before and after immunization) exhibited a higher ratio of $\operatorname{IgG} 1 / \operatorname{IgG} 2$ a compared to the control $(P<0.01, P<0.05$, Figure $1 \mathrm{C})$. After immunization, a significant increase in serum IL-4 concentration was also observed in PNE offspring ( $P<0.05$, Figure 1D).

\section{PNE altered the thymocyte phenotypes and increased thymocyte apoptosis in female offspring on PND 49}

Thymocyte apoptosis and thymopoiesis suppression were reported to be responsible for the immune impairments [29]. We analyzed the phenotypes and apoptosis of thymocytes on PND 49 by flow cytometry. As shown in Figure $2 \mathrm{~A}$ and $2 \mathrm{~B}$, the PNE female offspring exhibited a higher percentage of DN (the immature subpopulation of 
thymocytes) and lower percentages of DP and $\mathrm{CD}^{+} \mathrm{SP}$ than that of control $(P<0.05, P=0.058)$. Moreover, on PND 49 , the apoptosis percentages of total thymocytes, DP, and $\mathrm{CD}^{+} \mathrm{SP}$ of PNE female offspring were higher than that of control $(P<0.05$, Figure $2 \mathrm{C}$ and 2D).

PNE altered the thymocyte phenotypes and increased thymocyte apoptosis in the fetus

We further analyzed the thymocyte phenotypes and apoptosis in the fetus on gestational day (GD) 18 to explore the programming effects of PNE on fetal thymus development. As shown in Figure 3A and 3B, PNE fetuses exhibited significantly lower percentages of $\mathrm{DN}, \mathrm{CD}^{+} \mathrm{SP}$ and $\mathrm{CD}^{+}$SP thymocytes $(P<0.05)$. Consistent with the phenotypes, the apoptosis percentages of total thymocytes, $\mathrm{CD}^{+} \mathrm{SP}$ and $\mathrm{CD}^{+} \mathrm{SP}$ in $\mathrm{PNE}$ fetuses were increased compared with the control $(P<0.05$, Figure $3 \mathrm{C}$ and $3 \mathrm{D})$.

\section{In vitro}

\section{Nicotine treatment enhanced thymocyte apoptosis}

According to our in vivo results, prenatal nicotine exposure could induce programmed apoptosis of total and CD4 ${ }^{+}$SP thymocytes. Additionally, nicotine could pass the placental barrier due to its high lipid solubility and
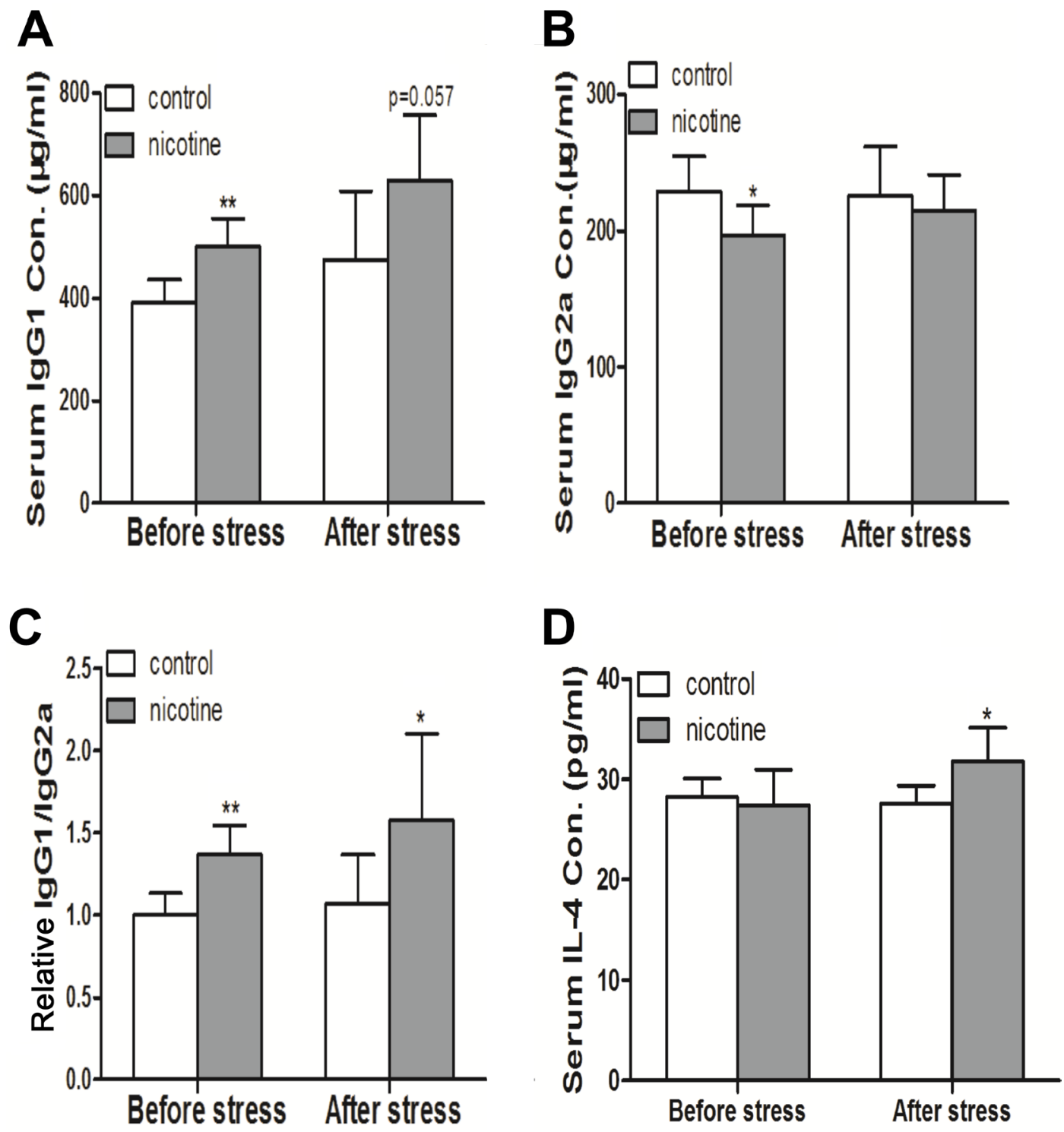

Figure 1: Effects of prenatal nicotine exposure on serum IgG1, IgG2a, and IL-4 production of female offspring on PND 49. The pregnant mice were exposed to $3 \mathrm{mg} / \mathrm{kg} / \mathrm{d}$ nicotine from GD 0 to GD 18 . After birth, the female offspring were maintained until PND 49. Half of the female offspring on PND 42 were immunized with $S$. pneumoniae for 7 days and were sacrificed after anesthesia on PND49. The contents of IL-4, IgG1, and IgG2a in serum were then analyzed. Difference among multiple groups was analyzed with oneway ANOVA. (A) Serum IgG1 concentration; (B) Serum IgG2a concentration; (C) The relative IgG1/IgG2a ratio which was standardized by taking the IgG1/IgG2a ratio of the control group as 1 ; (D) Serum IL-4 concentration. Mean $\pm \mathrm{SD}, n=7-8 .{ }^{*} P<0.05$, ${ }^{* *} P<0.01$ vs control. 
act on fetal thymocytes directly $[14,16]$. Accordingly, to investigate the direct pro-apoptotic effect of nicotine on thymocytes and the mechanisms, we cultured thymic primary cells from infant mice at 3 weeks of age, and treated the cells with $25-100 \mu \mathrm{M}$ nicotine for $48 \mathrm{~h}$ to analyze the dose-effect of nicotine on thymocyte apoptosis or $50 \mu \mathrm{M}$ nicotine for $24-72 \mathrm{~h}$ to analyze the time-effect of nicotine on thymocyte apoptosis. Thymocyte apoptosis was determined by flow cytometry. The dose-effect results showed that compared to the vehicle (Phosphate-buffered saline, PBS), 50 and $100 \mu \mathrm{M}$ nicotine significantly increased the apoptosis rates of total thymocytes to $13.9 \%(P<0.01)$ and $17.3 \%(P<0.01)$, respectively (Figure 4A and 4B). Meanwhile, 50 and $100 \mu \mathrm{M}$ nicotine also promoted $\mathrm{CD}^{+} \mathrm{SP}$ thymocyte apoptosis to $5.29 \%$ $(P<0.01)$ and $5.85 \%(P<0.01)$, respectively. The timeeffect results showed that $50 \mu \mathrm{M}$ nicotine treatment for 24 $\mathrm{h}$ had few effects on the apoptosis of thymocytes, while 48 and $72 \mathrm{~h}$ treatment of $50 \mu \mathrm{M}$ nicotine clearly augmented total thymocyte apoptosis to $11.6 \%(P<0.01)$ and $31.7 \%$ $(P<0.01)$ respectively and $\mathrm{CD}^{+} \mathrm{SP}$ thymocyte apoptosis to $4.31 \%(P<0.01)$ and $17.1 \%(P<0.01)$ respectively, compared with the control (Figure 4C and 4D). These results illustrated that nicotine promoted apoptosis in both concentration-dependent and time-dependent manners.

\section{Nicotine treatment upregulated the Fas apoptotic pathway}

The Fas apoptotic pathway was reported to mediate the apoptosis of thymocytes [8], and nicotine exerts its activity by binding $\alpha 7 \mathrm{nAChR}$. We then detected the expression of $\alpha 7 \mathrm{nAChR}$ and Fas and activities of caspase-3 and caspase-8. As shown in Figure 5A, 50 and $100 \mu \mathrm{M}$ nicotine treatments increased the mRNA expression of $\alpha 7 \mathrm{nAChR}$, Fas, casepase-3, and caspase-8, as compared with the control $(P<0.01, P<0.05)$. The protein expression of $\alpha 7 \mathrm{nAChR}$ and Fas and the activities of caspase- 3 and caspase- 8 in both the 50 and $100 \mu \mathrm{M}$ nicotine-treated groups were markedly higher than that of the control $(P<0.01, P<0.05$, Figure 5B-5D).

\section{Nicotine induced CpG demethylation of the Fas promoter}

Fas expression is activated by DNA demethylation at transcription level [22]. Therefore, we analyzed the DNA methylation of Fas promoter using MassArray. According to the concentration-dependent results of nicotine on the Fas apoptotic pathway, $50 \mu \mathrm{M}$ nicotine was selected to treat thymocytes. As shown in Table 1 although the average methylation rates of the Fas promoter were not changed after nicotine treatment, among those $\mathrm{CpG}$ sites, nt $+295,-2394$, and -2441 showed significantly decreased frequency of single $\mathrm{CpG}$ methylation after nicotine treatment $(P<0.05)$, and the methylation level on $n t+456$ also showed a decreasing trend $(P=0.06)$.

\section{Increased TET2 mediated nicotine-induced Fas promoter demethylation in thymocytes}

To investigate the mechanisms of nicotineinduced Fas demethylation, the expression of DNA methyltransferases (Dnmts) and TETs, two known key regulators of DNA methylation modification enzymes,
A
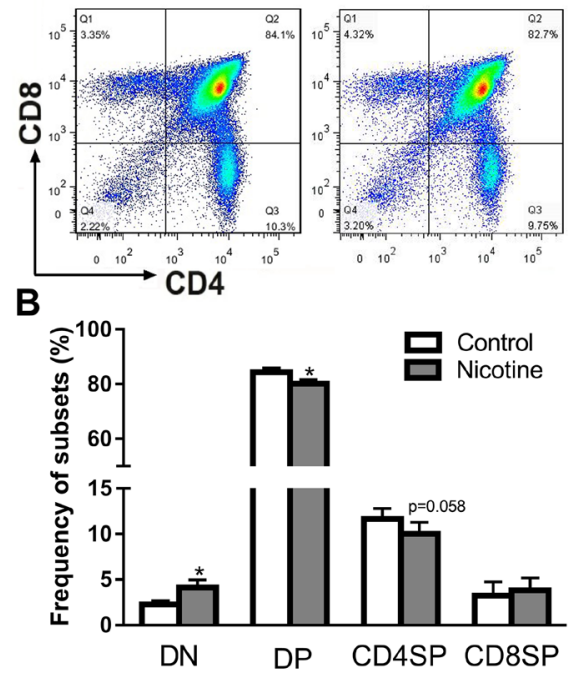

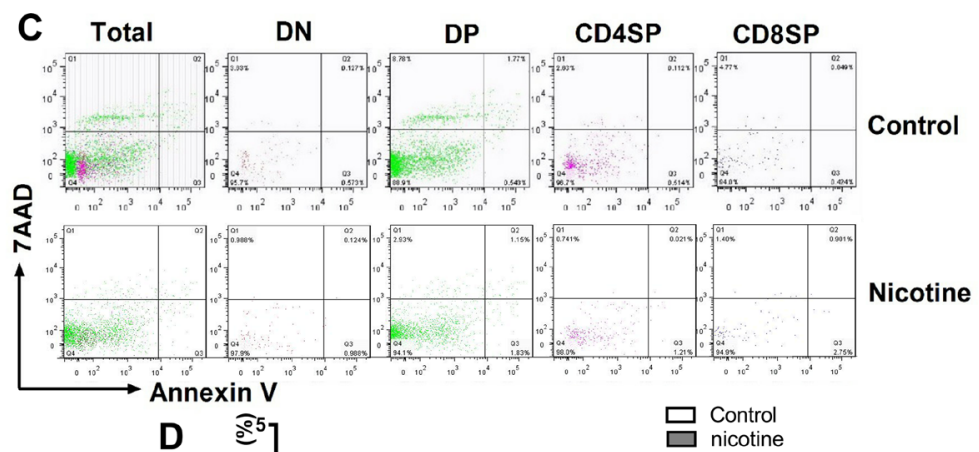

D

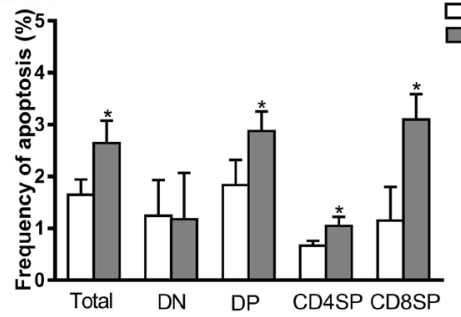

Figure 2: Effects of prenatal nicotine exposure on the thymocyte phenotypes and apoptosis frequency in female offspring on PND 49. Female offspring were sacrificed after anesthesia on PND 49 and thymuses were harvested and dissociated over the $40 \mu \mathrm{m}$ stainless steel to prepare single thymocyte suspensions. Then the thymocytes were stained with $100 \mu \mathrm{l}$ of antibody cocktail (FITC-CD3, APC-CD4 and PE-cy7-CD8) to identify thymocyte phenotypes. Annexin V/PE apoptosis detection kit was also used to determined thymocyte apoptosis frequency. (A) Typical flow diagram of thymocyte phenotypes; (B) Frequency of thymocyte subsets; (C) Typical flow diagram of thymocyte apoptosis; (D) Apoptosis frequency of thymocytes. The difference was analyzed with $t$-test. Mean \pm $\mathrm{SD}, n=3-4 .{ }^{*} P<0.05$ vs control. 
were detected. As shown in Figure 6A, the expression of Dnmt1, Dnmt3a, Dnmt3b, TET1, and TET3 in thymocytes showed no difference between the nicotine group and control, but notably increased TET2 expression was observed after $50 \mu \mathrm{M}$ and $100 \mu \mathrm{M}$ nicotine treatment $(P<0.05)$. Consistent with this result, an increased TET2 protein level was also observed in nicotine-treated thymocytes $(P<0.05$, Figure 6B).
A
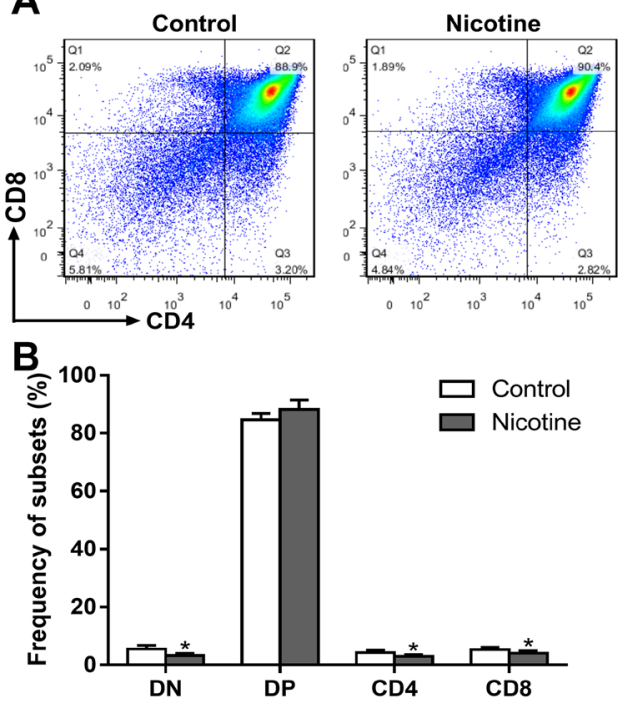

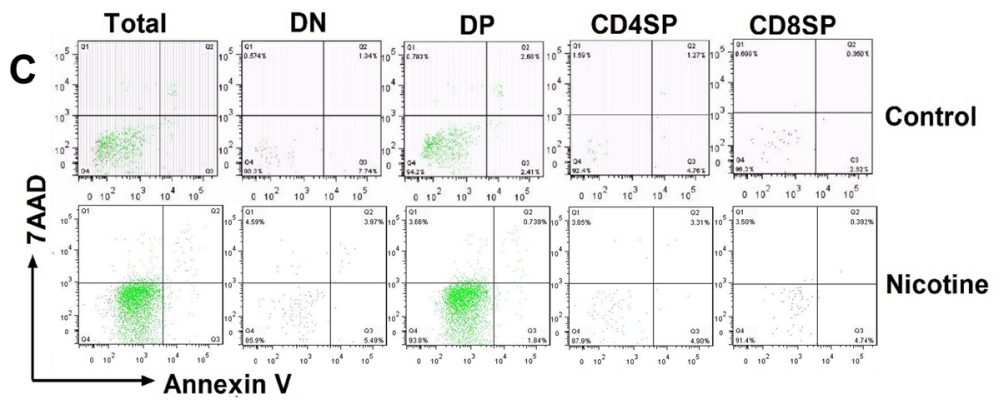

D

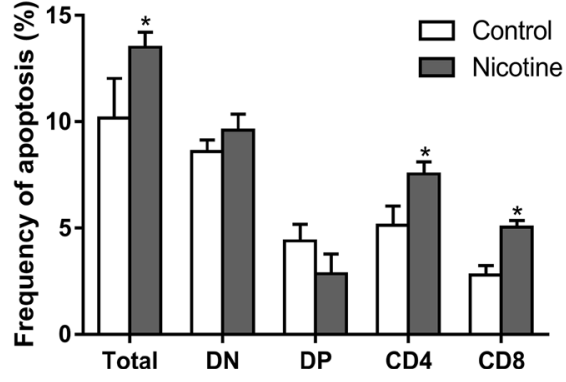

Figure 3: Effects of prenatal nicotine exposure on the thymocyte phenotypes and apoptosis frequency in the fetus on GD 18. Pregnant mice were sacrificed after anesthesia on GD 18. Fetuses were removed quickly from the uterus and decapitated after euthanasia. The fetal thymus from each littermate were collected and pooled into one sample for flow cytometry detection. (A) Typical flow diagram of thymocyte phenotypes; (B) Frequency of thymocyte subsets; (C) Typical flow diagram of thymocyte apoptosis; (D) Apoptosis frequency of thymocyte. The difference was analyzed with $t$-test. Mean $\pm \mathrm{SD}, n=3-4 .{ }^{*} P<0.05$ vs control.
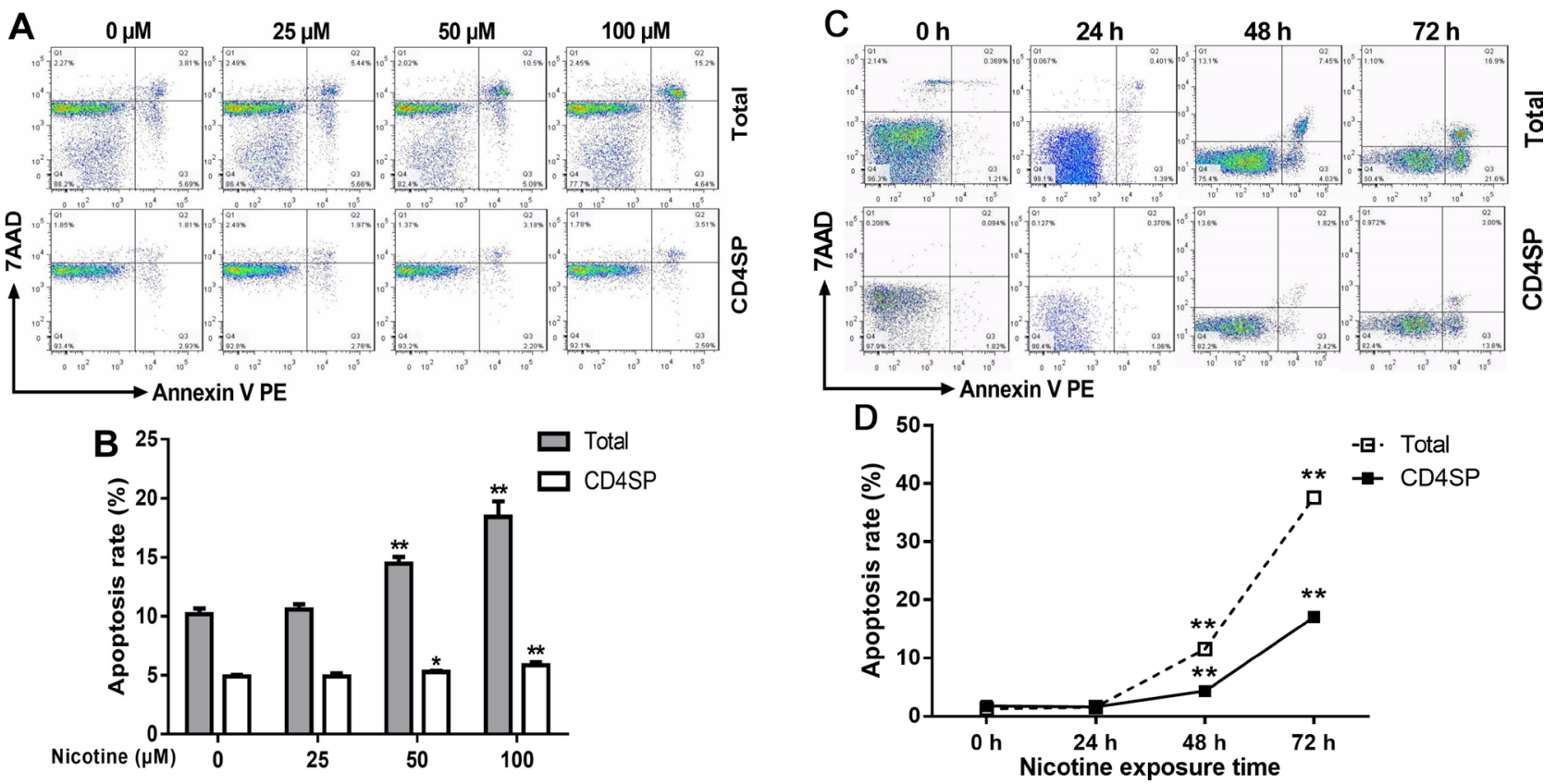

Figure 4: Effect of nicotine treatment in vitro on the apoptosis of primary thymocytes. Thymus lobes dissected from infant mice at 3 weeks of age were gently dissociated over the stainless steel sieve. The cells were treated with different concentrations $(25,50$ and $100 \mu \mathrm{M})$ of nicotine for 48 hours or $50 \mu \mathrm{M}$ of nicotine for $24 \mathrm{~h}, 48 \mathrm{~h}$ and $72 \mathrm{~h}$. The apoptosis frequency was determined by flow cytometry. (A, C) Typical flow diagram of thymocyte apoptosis; (B) Effects of different concentrations of nicotine $(0-100 \mu \mathrm{M})$ on thymocyte apoptosis; (D) Effects of $50 \mu \mathrm{M}$ nicotine exposure for different time $(0,24,48,72 \mathrm{~h})$ on thymocyte apoptosis. The difference was analyzed with $t$-test. Mean $\pm \mathrm{SD}, n=3-4 .{ }^{*} P<0.05,{ }^{* *} P<0.01$ vs control. 
To further explore the role of TET2 in nicotineinduced Fas demethylation, thymocytes were transfected by exogenous TET2 siRNA to inhibit TET2 protein expression prior to nicotine treatment. The results showed that the TET2 siRNA transfection clearly reversed the effect of nicotine-promoted TET2 increase and further abolished the single CpG demethylation of $\mathrm{nt}+295$, $+456,-2394$, and -2441 in the Fas promoter (Table 1). As shown in Figure 6C, TET2 siRNA transfection could also abrogate the nicotine-induced Fas increase. Moreover, data from flow cytometry showed that the TET2 siRNA transfection could also abolish the nicotine-induced thymocyte apoptosis in both total and $\mathrm{CD} 4^{+} \mathrm{SP}$ thymocytes (Figure 6D).

$\alpha 7$ nAChR mediated nicotine-induced DNA demethylation of the Fas promoter and the following upregulation of Fas-mediated thymocyte apoptosis

To further investigate the role of $\alpha 7 \mathrm{nAChR}$ in TET2-mediated Fas demethylation, thymocytes were pretreated with an $\alpha 7 \mathrm{nAChR}$ specific antagonist $\alpha$-bungarotoxin $30 \mathrm{~min}$ prior to nicotine treatment. Then TET2 expression, the methylation status of Fas promoter, the expression of the Fas apoptotic pathway and thymocyte apoptosis were determined. As shown in Figure 7A, the expression of TET2 was significantly decreased after $\alpha$-bungarotoxin pre-incubation compared
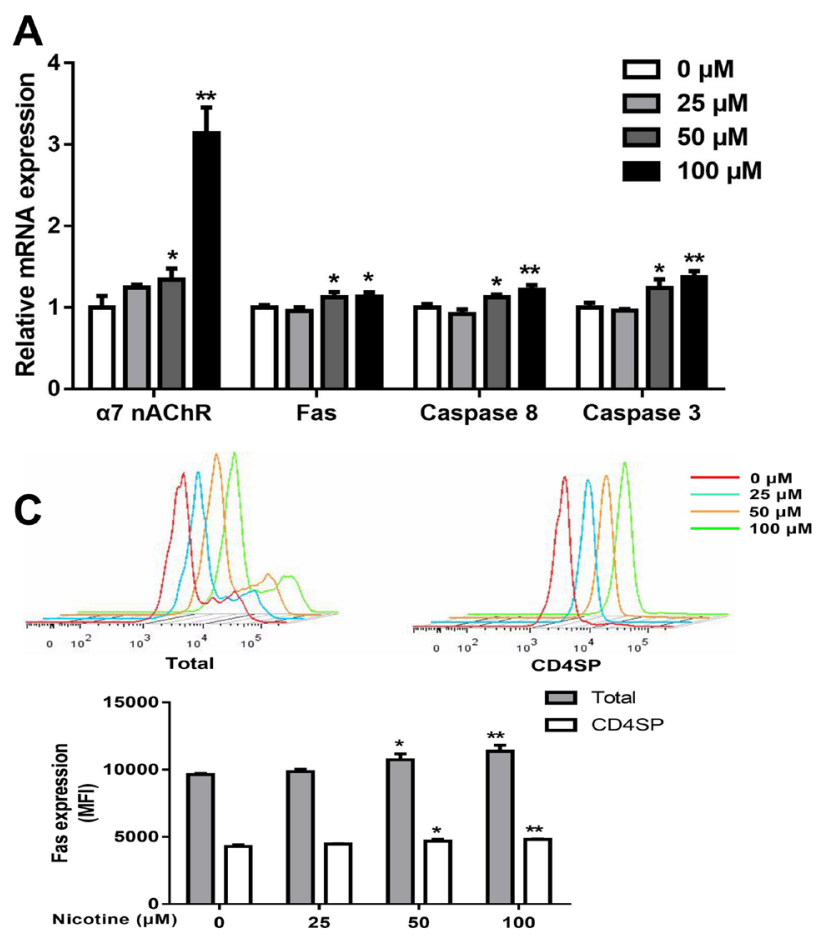

Figure 5: Effects of nicotine ( $(0$ to $100 \mu \mathrm{M})$ treatment for $48 \mathrm{~h}$ on expression of $\alpha 7 \mathrm{nAChR}$ and expression of Fas apoptotic pathway in primary thymocytes. (A) mRNA expression of $\alpha 7$ nAChR, Fas, Caspase- 8 and Caspase- 3 was detected using qPCR in thymocytes. (B) a7 nAChR protein expression was determined by western blot in thymocytes. (C) Fas protein expression in thymocytes. Thymocytes were stained with CD95-PE-cy7, and the expression of Fas protein was analyzed by flow cytometry. (D) The Caspase- 8 and Caspase-3 protein activities were detected using the Caspase activity kits. The difference was analyzed with one-way ANOVA. Mean $\pm \mathrm{SD}, n=3-4 .{ }^{*} P<0.05,{ }^{* *} P<0.01$ vs control.

with the nicotine group $(P<0.05)$. The TET2-induced single CpG demethylation on the $n t+295,+456,-2394$, and -2441 in the Fas promoter were obviously abolished by pre-incubation of $\alpha$-bungarotoxin (Table 1). The results of flow cytometry and qPCR further showed that the preincubation of $\alpha$-bungarotoxin clearly abolished the effect of nicotine-induced total and $\mathrm{CD} 4^{+} \mathrm{SP}$ thymocyte apoptosis and upregulated Fas, caspase- 8 and caspase- 3 activities (Figure 7B-7D).

\section{DISCUSSION}

The dose of $3 \mathrm{mg} / \mathrm{kg} / \mathrm{d}$ of nicotine and the Balb/C strain were widely used to establish the PNE model for representing prenatal cigarette smoke exposure [3032]. The $3 \mathrm{mg} / \mathrm{kg} / \mathrm{d}$ dose of nicotine used in this study could equate to a moderate smoker during pregnancy (exposure to 6-8 cigarettes per day) [33, 34]. A mouse embryo starts implantation on GD 4.5 till GD 6.5 , and the fetal thymus organogenesis is initiated on GD 11.5 and continues until birth $[29,35]$. Therefore, the exposure period from GD 9 to GD 18 not only covered the period of fetal thymus organogenesis and development but also protected the embryo implantation from the influence of nicotine. In fact, no miscarriage or stillborn fetuses have been observed in our study. Nicotine levels in fetal
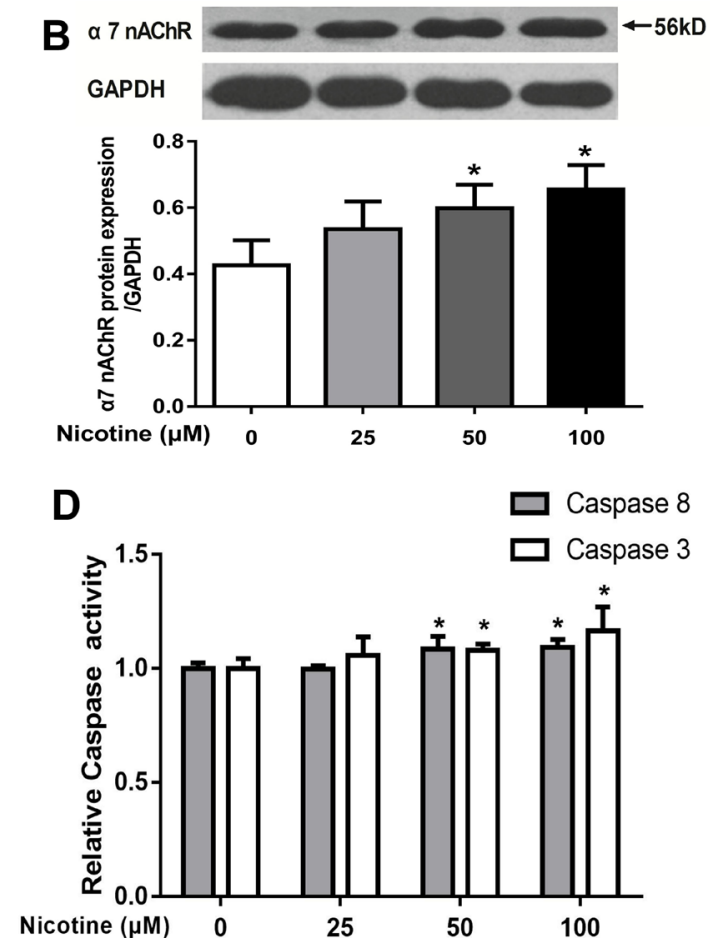

www.impactjournals.com/oncotarget 
Table 1: CpG methylation levels in Fas promoter

\begin{tabular}{lcccc}
\hline CpG site (bp) & Control & Nicotine & Nicotine+TET2 siRNA & Nicotine+ $\boldsymbol{\alpha B T X}$ \\
\hline-2469 & $25.67 \pm 0.47$ & $26.33 \pm 0.94$ & $25.67 \pm 1.25$ & $18.67 \pm 8.34$ \\
-2441 & $13.00 \pm 0.00$ & $11.00 \pm 0.00^{*}$ & $13.00 \pm 1.63$ & $10.33 \pm 1.25$ \\
-2394 & $10.00 \pm 1.63$ & $4.00 \pm 0.82^{*}$ & $7.67 \pm 3.30$ & $8.00 \pm 4.00$ \\
-2384 & $8.00 \pm 0.00$ & $8.00 \pm 0.82$ & $7.00 \pm 1.64$ & $10.50 \pm 0.50$ \\
-2353 & $25.67 \pm 0.47$ & $26.33 \pm 0.94$ & $25.67 \pm 1.25$ & $18.67 \pm 8.34$ \\
-2332 & $11.00 \pm 2.17$ & $13.67 \pm 4.64$ & $15.00 \pm 3.74$ & $18.00 \pm 4.24$ \\
-2291 & $19.67 \pm 1.70$ & $18.33 \pm 0.47$ & $19.67 \pm 0.47$ & $22.00 \pm 2.16$ \\
$-2257:-2261$ & $32.67 \pm 2.87$ & $33.67 \pm 2.62$ & $30.00 \pm 2.94$ & $33.00 \pm 1.00$ \\
-2164 & $19.67 \pm 1.70$ & $18.33 \pm 0.47$ & $19.67 \pm 0.47$ & $22.00 \pm 2.16$ \\
+174 & $\mathrm{~N} . \mathrm{D}$. & $\mathrm{N} . \mathrm{D}$. & $\mathrm{N} . \mathrm{D}$. & $0.67 \pm 0.94$ \\
+210 & $8.33 \pm 0.94$ & $8.67 \pm 0.94$ & $11.00 \pm 0.82$ & $9.00 \pm 1.41$ \\
+250 & $\mathrm{~N} . \mathrm{D}$. & $1.33 \pm 1.89$ & $\mathrm{~N} . \mathrm{D}$. & N.D. \\
+295 & $6.00 \pm 0.00$ & $4.00 \pm 0.00^{*}$ & $8.67 \pm 2.05$ & $6.00 \pm 2.94$ \\
+332 & $7.67 \pm 2.05$ & $7.00 \pm 0.82$ & $6.67 \pm 0.82$ & $9.00 \pm 1.63$ \\
$+417:+422$ & $4.00 \pm 0.82$ & $4.00 \pm 1.63$ & $4.00 \pm 0.82$ & $3.67 \pm 0.94$ \\
+456 & $9.67 \pm 1.25$ & $7.00 \pm 0.82 p=0.06$ & $12.00 \pm 2.16$ & $12.33 \pm 1.89$ \\
+464 & $\mathrm{~N} . \mathrm{D}$. & $\mathrm{N} . \mathrm{D}$. & $\mathrm{N} . \mathrm{D}$. & N.D. \\
+540 & $7.00 \pm 1.41$ & $6.33 \pm 4.11$ & $8.67 \pm 0.47$ & $8.33 \pm 0.47$ \\
+570 & $\mathrm{~N} . \mathrm{D}$. & $\mathrm{N} . \mathrm{D}$. & $\mathrm{N} . \mathrm{D}$. & N.D. \\
+596 & $21.33 \pm 2.87$ & $18.67 \pm 2.36$ & $18.00 \pm 2.45$ & $18.33 \pm 2.05$ \\
Average & $11.47 \pm 2.05$ & $10.83 \pm 2.09$ & $11.62 \pm 1.95$ & $11.43 \pm 1.91$ \\
\hline
\end{tabular}

The CpG methylation levels in the Fas promoter ( -2480 bp to -2141 bp and 174 bp to 596 bp) were detected by MassARRAY method. DATA were analyzed with one-way ANOVA. Mean $\pm \mathrm{SD}, n=3$ cell samples per group, ${ }^{*} p<0.05$ vs. control. N.D.: non-detected.

circulation and fetal tissues can be much higher than that in the maternal serum due to free penetration of placenta and lipophilic accumulation of nicotine over the course of 10 -month pregnancy, and low enzymatic activity of fetal CYP2A6 $[14,36]$. Thus, much higher concentrations up to 100 or even $300 \mu \mathrm{M}$ have been utilized in many shortterm (several days) in vitro cell culture studies [37-40]. Therefore, $0-100 \mu \mathrm{M}$ nicotine treatment were used for mechanism research in vitro. The $S$. pneumoniae used in the present study is a T cell-dependent antigen, which can induce the immune system to produce cytokines (such as IL-4) and IgG antibodies [34]. It was evident that females are more susceptible to immune disorders. Hence, in this study, female offspring were retained after birth to study the postnatal immunotoxicity of PNE.

Prenatal cigarette smoke exposure could induce thymus atrophy in the fetus and result in allergy-prone deviation in the T-cell response, which manifests as increased IL-4 production during allergic disease development, in postnatal life [28, 41, 42]. Evidence also showed that PNE is related to increased production of inflammatory cytokines after birth [43]. Additionally, Abbas and Vadesilho reported that the increased IL-4 production could cause an abnormal increase of the ratio of $\operatorname{IgG} 1 / \operatorname{IgG} 2$, which in turn polarized the offspring immune system toward immune diseases [44, 45]. Additionally, our previous study showed that the PNE male offspring showed an increased IgG1/IgG2a ratio and higher IL-4 content after antigen stimulation [34]. In this study, the changes in the IgG1, IgG2a, and IL-4 contents in PNE female offspring were different from those of the males. After S. pneumoniae immunization, the female PNE offspring also showed increased IL-4 content and an increased ratio of $\operatorname{IgG} 1 / \operatorname{IgG} 2$. These findings confirmed our hypothesis that PNE could cause immune disorders in offspring.

Accelerated apoptosis of fetal thymocytes is one of the most important reasons for postnatal immune impairments induced by prenatal adverse factors, such as smoke, glucocorticoids, TCDD and diethylstilbestrol [46-50]. In our study, the apoptosis percentages of fetal total and $\mathrm{CD}^{+} \mathrm{SP}$ thymocytes in PNE fetus and in PNE offspring were higher than that of control. Moreover, the reduced cell proportion of $\mathrm{CD}^{+} \mathrm{SP}$ was consistent with the increased apoptosis at the two time points. These findings suggested that PNE could decrease $\mathrm{CD}^{+} \mathrm{SP}$ through 
increasing its apoptosis percentages, and this effect could persist in postnatal life. Due to $\mathrm{CD}^{+} \mathrm{SP}$ thymocyte development is essential for the establishment of the $\mathrm{CD}^{+} \mathrm{T}$ helper cell immune network [45]. Researchers have found that the reduction of periphery $\mathrm{CD}^{+} \mathrm{T}$ cells was tightly related to increased IL-4 and IgG1 production following immunization in offspring [51]. This persistent increase of $\mathrm{CD}^{+} \mathrm{SP}$ apoptosis in our study might be the potential explanation for PNE-induced immune impairments in female offspring.

In recent years, different studies have presented conflicting data while investigating the effects of nicotine on cell apoptosis. These contradictory results may be due to the different duration of exposure and the maturation of cells [15]. In in vivo studies, almost all animal models that had a long exposure time or high dose of nicotine showed pro-apoptotic effects [15]. Additionally, researchers reported that nicotine showed a more typical anti-apoptotic effect on well-developed cells but a strong pro-apoptotic effect on immature or developing cells [19, 52, 53]. In in vitro studies, Middlebrook et al. reported that the proapoptotic effects of nicotine might act only on immature thymocytes or thymocyte precursors [16]. The increasing doses $\left(10^{-8}-10^{-4} \mathrm{M}\right)$ of nicotine showed different effects on cell validity and the lower dose of nicotine treatment exerts higher anti-apoptotic effects on thymoma cells [54]. Additionally, the thymopoiesis process is tightly controlled, and almost $95 \%$ of thymocytes were eliminated through apoptosis during this process [29]. Thymocytes are vulnerable to xenobiotics during the thymopoiesis [1]. In the present study, the thymocyte is the immature immune cell, and nicotine is easier to accumulate and more difficult to be remove in fetus $[14,36]$. Nicotine exposure from GD 9 to GD 18 may provide a "long-term exposure to a high dose of nicotine" micro-environment for thymocytes and lead to apoptosis. The results from our in vitro data further confirmed that exposure to nicotine for a longer duration or at a higher dose could induce more significant apoptosis of both total and $\mathrm{CD}^{+} \mathrm{SP}$ thymocytes.

In the immune system, nicotine induces its actions by binding to $\alpha 7 \mathrm{nAChR}$, which is involved in directly inducing the apoptosis of immune cells [15]. Slotkin et al. showed that prenatal nicotine-induced apoptosis was
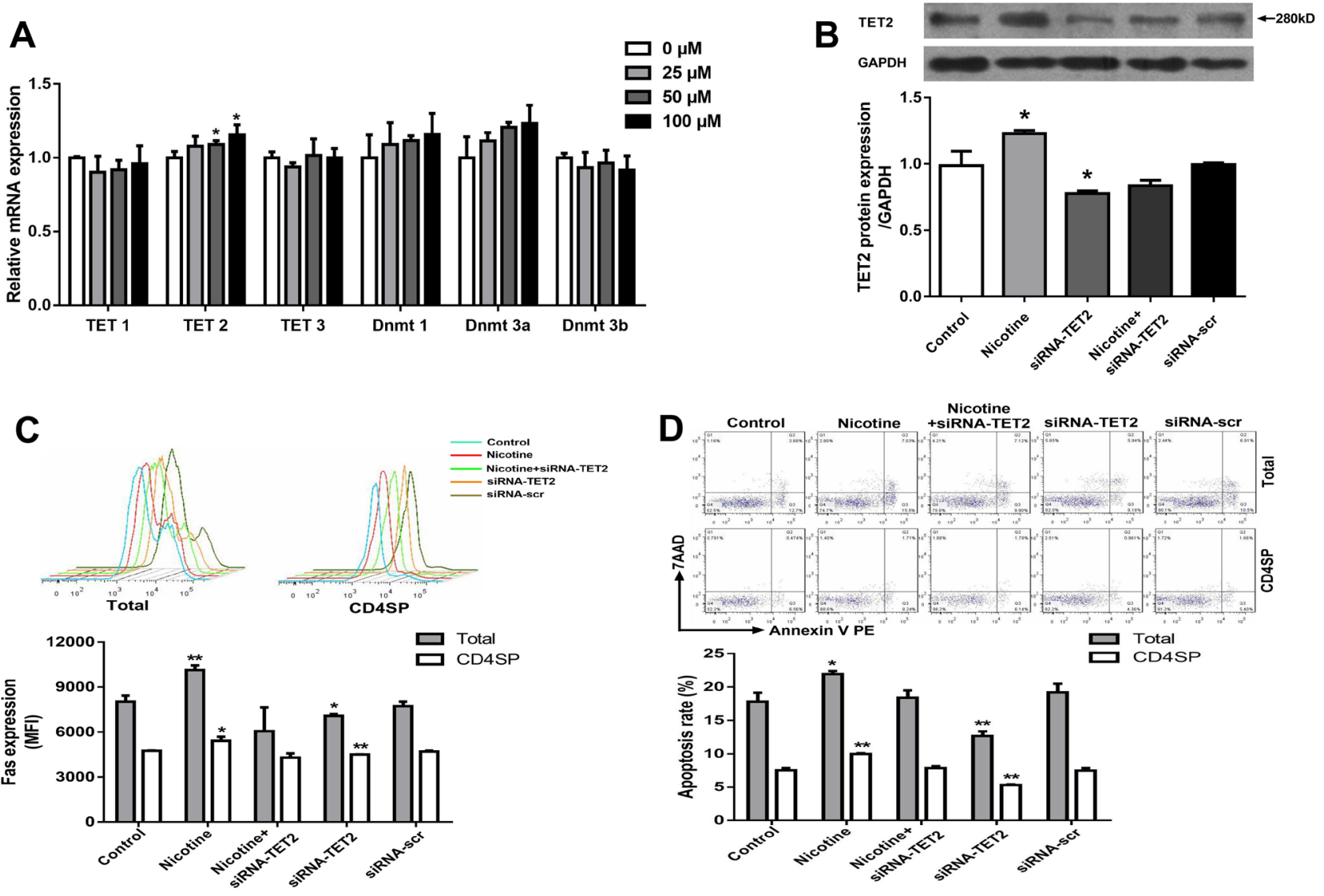

Figure 6: Effects of $50 \mu \mathrm{M}$ nicotine treatment for 48 hours with or without siRNA-TET2 (100 nM) transfection on thymocyte apoptosis and expression of TET2, $\mathbf{\alpha} 7 \mathrm{nAChR}$ and Fas in primary thymocytes. (A) The mRNA expression of TET1, TET2, TET3, Dnmt1, Dnmt2a, and Dnmt3b was detected using qPCR. To explore the role of TET2 in the DNA methylation of the Fas gene, TET2 siRNA $(100 \mathrm{nM})$ transfection was performed using Lipofectamine 3000 reagent, and TET2 protein expression was determined by western blot. (B) TET2 protein expression. (C) Fas protein expression. (D) Apoptosis frequency of thymocyte. The difference was analyzed with one-way ANOVA. Mean $\pm \mathrm{SD}, n=3-4 .{ }^{*} P<0.05,{ }^{* *} P<0.01$ vs control. 
mediated via nAChR activation and increased nAChR concentrations [55]. In addition, Vivek et al. also reported that the expression of $\alpha 7 \mathrm{nAChR}$ was increased following prenatal cigarette exposure and it coincided with the changes of caspase expression [19]. Consistent with these studies, after 0-100 $\mathrm{mM}$ nicotine treatments in vitro in the present study, the mRNA and protein expression of $\alpha 7$ nAChR were significantly increased in a concentrationdependent manner and were associated with upregulated Fas, caspase- 3 and caspase- 8 in thymocytes. Further, the $\alpha 7 \mathrm{nAChR}$ antagonist $\alpha$-bungarotoxin not only abrogated nicotine-mediated pro-apoptotic effects but also reversed the nicotine-upregulated Fas apoptotic pathway. These findings suggested that $\alpha 7 \mathrm{nAChR}$ might be indispensable in Fas-mediated pro-apoptotic effects in nicotine-treated thymocytes.
Our previous studies showed that PNE could regulate DNA methylation of genes in developing organs (such as StAR and acetoacetyl-CoA in fetal adrenal) $[25,26]$. DNA methylation is a major epigenetic mechanism that control Fas gene expression at the level of transcription $[22,56]$. And both Gazin and Thaler reported that two regions in the Fas promoter $(-2,600$ bp to $-2200 \mathrm{bp} ;-30 \mathrm{bp}$ to $623 \mathrm{bp}$ ) are rich in $\mathrm{CpG}$ sites $[56,57]$. Our pre-experiment further confirmed that the $\mathrm{CpG}$ dinucleotide centered on this two regions ( $-2480 \mathrm{bp}$ to $-2141 \mathrm{bp}$ and $174 \mathrm{bp}$ to $596 \mathrm{bp}$ ) in the Fas promoter (Supplementary Figure 1). Accordingly, the methylation status within these two $\mathrm{CpG}$-rich regions was detected in the present study, and the results showed that the $\mathrm{CpG}$ methylation levels on $\mathrm{nt}+295,-2394$, and -2441 were significantly decreased, which indicated that nicotine
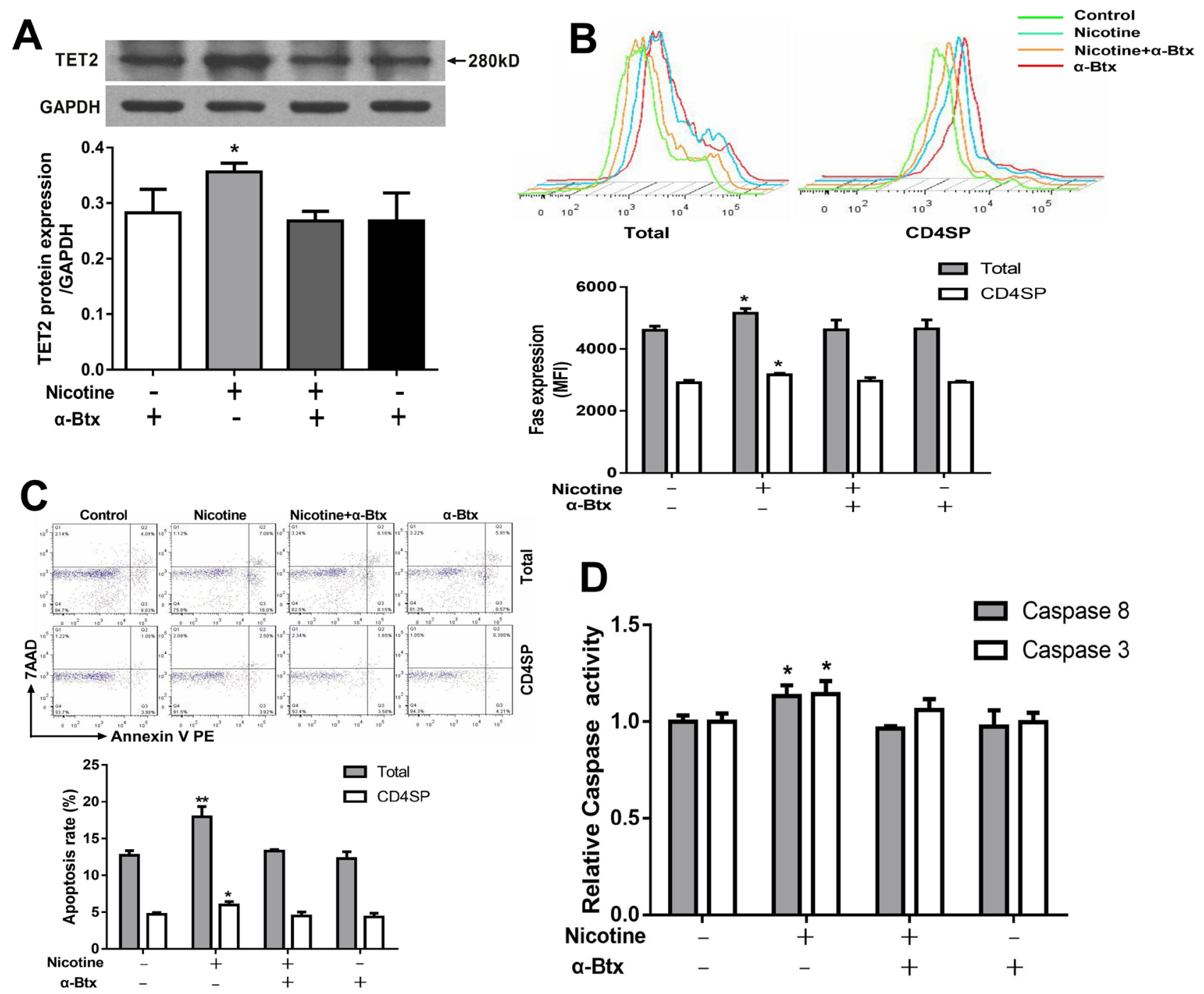

Figure 7: Effects of $50 \mu \mathrm{M}$ nicotine treatment with or without $\alpha$-bungarotoxin $(\alpha-B t x, 1 \mu g)$ pretreatment on thymocyte apoptosis and expression of TET2 and Fas apoptotic pathway in primary thymocytes. To investigate the role of $\alpha 7 \mathrm{nAChR}$ in nicotine-mediated apoptosis, thymocytes were pretreated with $1 \mu \mathrm{g} / \mathrm{ml}$ of $\alpha$-Btx half an hour before nicotine treatment. (A) TET2 protein expression was determined by western blot. (B) Fas protein expression. (C) Apoptosis frequency of thymocyte. (D) The Caspase-8 and Caspase-3 protein activities were detected using the Caspase activity kits. The difference was analyzed with one-way ANOVA. Mean $\pm \mathrm{SD}$, $n=3-4 .{ }^{*} P<0.05,{ }^{* *} P<0.01$ vs control. 
could induce Fas expression through promoting DNA demethylation of the Fas promoter.

Two families (Dnmt family enzymes; TET family enzymes) of enzymes have been identified as regulating DNA methylation and demethylation [58]. In the present study, we first detected mRNA expression of Dnmts and TETs to preliminarily identify which enzyme might be the mediator of the methylation modification of the Fas promoter in thymocytes following nicotine treatment. We found that only TET2 expression increased significantly. The western blot analysis also showed a dose-dependent increase in protein expression of TET2 after nicotine treatment. Moreover, the results of a TET2 siRNA transfection experiment showed abolished nicotineinduced Fas demethylation, which further confirmed that TET2 mediated the nicotine-induced DNA demethylation of the Fas promoter. Now there is lacking of knowledge about how TET2 demethylates FAS yet. During T cell development, two key transcription factors, Smad3 and STAT5, were reported to be involved in promoting the TET2 demethylation [59]. Following TET increases, Smad3 could facilitate the TET1 and TET2 binding to the promoter of target genes [59]. Another study also showed that the Smad3 was an upstream signal of the Fas apoptotic pathway, and the Smad3 knockdown could effectively inhibited the Fas expression and the caspase activation [60]. Thus, we supposed that, in thymocytes, the increased TET2 might also be facilitated by Smad 3 onto Fas promoter and then induce Fas promoter demethylation. Although no report is available on whether $\alpha 7 \mathrm{nAChR}$ activation is associated with TET2 expression, Nair VS et al. reported that TCR signaling could upregulate TET2 expression during T cell development [61]. It was reported that $\alpha 7 \mathrm{nAChR}$ could release similar signals in thymocyte as TCR signaling $[16,62]$. As a TCR downstream signaling, NF- $\kappa \mathrm{B}$ signaling was reported to be widely involve in thymocyte development following the TCR activation $[63,64]$. A study published recently showed that TET2 expression could be induced by LPS stimulation in

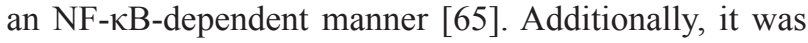
proved that the $\alpha 7 \mathrm{nAChR}$ activation could upregulate the NF- $\kappa B$ signaling [66-68]. Hence, the NF- $\mathrm{kB}$ signaling might be the downstream of $\alpha 7 \mathrm{nAChR}$ to activate TET2 . In the present study, we found that $\alpha$-bungarotoxin clearly abolished the effect of nicotine-promoted TET2 expression, which confirmed that TET2 expression was activated by $\alpha 7 \mathrm{nAChR}$. Further, with the pre-incubation of $\alpha$-bungarotoxin, the methylation level of Fas in the nicotine group is comparable with the control. These findings suggested that $\alpha 7 \mathrm{nAChR}$ mediated nicotineinduced TET2 expression and the following Fas promoter demethylation.

In summary, PNE directly increased the apoptosis of total and $\mathrm{CD} 4^{+} \mathrm{SP}$ thymocyte in the fetus, which persisted into postnatal life and resulted in immune impairments in female offspring. The underlying molecular mechanisms
(Figure 8) of the pro-apoptotic effects of nicotine might be that nicotine activates the $\alpha 7 \mathrm{nAChR}$ on thymocyte and increases TET2 expression, which could subsequently induce DNA demethylation of the Fas promoter followed by increased Fas expression and an upregulated Fas apoptotic pathway in thymocyte. Our findings showed, for the first time, that $\alpha 7 \mathrm{nAChR}$ could increase TET2 expression and Fas demethylation, and provided an epigenetic mechanism for elucidating the pro-apoptotic effects of nicotine on thymocytes. Our results also provided evidence for exploring the developmental origin of immune disease susceptibility in PNE offspring.

\section{MATERIALS AND METHODS}

\section{Chemicals and reagents}

Nicotine and $\alpha$-bungarotoxin were purchased from Sigma-Aldrich (St. Louis, MO, USA). Monoclonal antibodies (anti-mouse CD3-FITC, anti-mouse CD4-APC, anti-mouse CD8-PE-cy7, Rat IgG2b K Isotype Control FITC, Rat IgG2b K Isotype Control APC and Rat IgG2a K Isotype Control PE-cy7) and Annexin V/PE Apoptosis Detection kit were purchased from eBioscience (San Diego, USA). Anti-mouse CD95-PE-cy7 was obtained from BD Biosciences (New Jersey, USA). Mouse IgG1 and IgG2a ELISA kits were obtained from MultiSciences (Hangzhou, Zhejiang, China). Mouse IL-4 ELISA kit was obtained from Dakewe Biotech (Shenzhen, Guangdong, China). Anti-a7 nAChR and anti-TET2 were obtained from Abcam (San Diego, USA). Trizol was purchased from Life Technologies (Gaithersburg, MD, USA). Reverse transcription and RT-qPCR kits were purchased from TaKaRa Biotechnology (Dalian, Liaoning, China). RPMI-1640 medium and fetal bovine serum (FBS) were purchased from HyClone (Logan, UT, USA). Caspase-3 Action Detection kit and Caspase-8 Action Detection kit were from Beyotime Biotechnology (Shanghai, China). The TET2 siRNA and all primers were synthesized by Sangon Biotech Co., Ltd. (Shanghai, China). The TIANamp Genomic DNA Kit was from TIANGEN Biotech Co., Ltd. (Beijing, China). All chemicals and reagents were analytical grade.

\section{Animals}

The animal experiments were approved by the Committee on the Ethics of Animal Experiments at the Wuhan University School of Medicine (Permit Number: 14016). All protocols were performed according to the Guidelines for the Care and Use of Laboratory Animals of the Chinese Animal Welfare Committee and the International Council on Research Animal Care. The virgin female $(22 \pm 2 \mathrm{~g})$ and male $(25 \pm 2 \mathrm{~g}) \mathrm{Balb} / \mathrm{C}$ mice for in vivo experiment and the infant mice at age of 3 weeks $(14 \pm 1 \mathrm{~g})$ for in vitro experiment were obtained 
from the Experimental Center of Hubei Medical Scientific Academy (No. 2008-0005, Wuhan, Hubei, China). The animal experiments were performed in the Center for Animal Experiment of Wuhan University (Wuhan, Hubei, China), which has been accredited by the Association for Assessment and Accreditation of Laboratory Animal Care International (AAALAC).

\section{In vivo experiments}

\section{Animal treatment}

As shown in Supplementary Figure 2, female mice were mated with male mice at 2:1 overnight, after a oneweek acclimation. The day was declared as GD 0 by the presence of a vaginal plug in the vagina. The pregnant mice were randomly assigned to the PNE group or control group. The pregnant mice of the PNE group were subcutaneously administered $1.5 \mathrm{mg} / \mathrm{kg}$ of nicotine twice per day from GD 9 to GD 18. The mice of the control group were administered the same volume of saline at the same frequency and intervals. On GD 18, some pregnant mice were sacrificed under isoflurane anesthesia and then the fetuses from 3 litters (each litter 6-8 fetuses) per group were obtained and decapitated after euthanasia. The fetal thymus from each littermate was collected and pooled into one sample. These 3 pooled thymus samples per group were used for flow cytometry detection as a three-time repeated experiment.

The other pregnant mice were housed until delivery, and on PND 0, the numbers of infants were normalized to 6 infants per dam to assure adequate and standardized nutrition. The female offspring were weaned on PND 21. On PND 42, half of the female offspring (8-10 mice per group) were subcutaneously administered an $S$. pneumoniae vaccine to establish an inflammation model. Then, the animals were anesthetized with isoflurane and sacrificed to collect blood samples 7 days later (on PND 49). The thymuses of 3 female offspring per group were harvested for flow cytometry. Serum (from 8-10 female offspring per group) was stored at $-80^{\circ} \mathrm{C}$ for measurement of IL-4, IgG1, and IgG2a concentrations.

\section{Flow cytometry}

The thymus was cut into small pieces and gently mashed through a $40 \mu \mathrm{m}$ stainless steel sieve. Single cells were obtained by centrifugation at $335 \times \mathrm{g}$ for 5 min at $4{ }^{\circ} \mathrm{C}$ and resuspended at $1 \times 10^{7}$ cells $/ \mathrm{ml}$ in flow

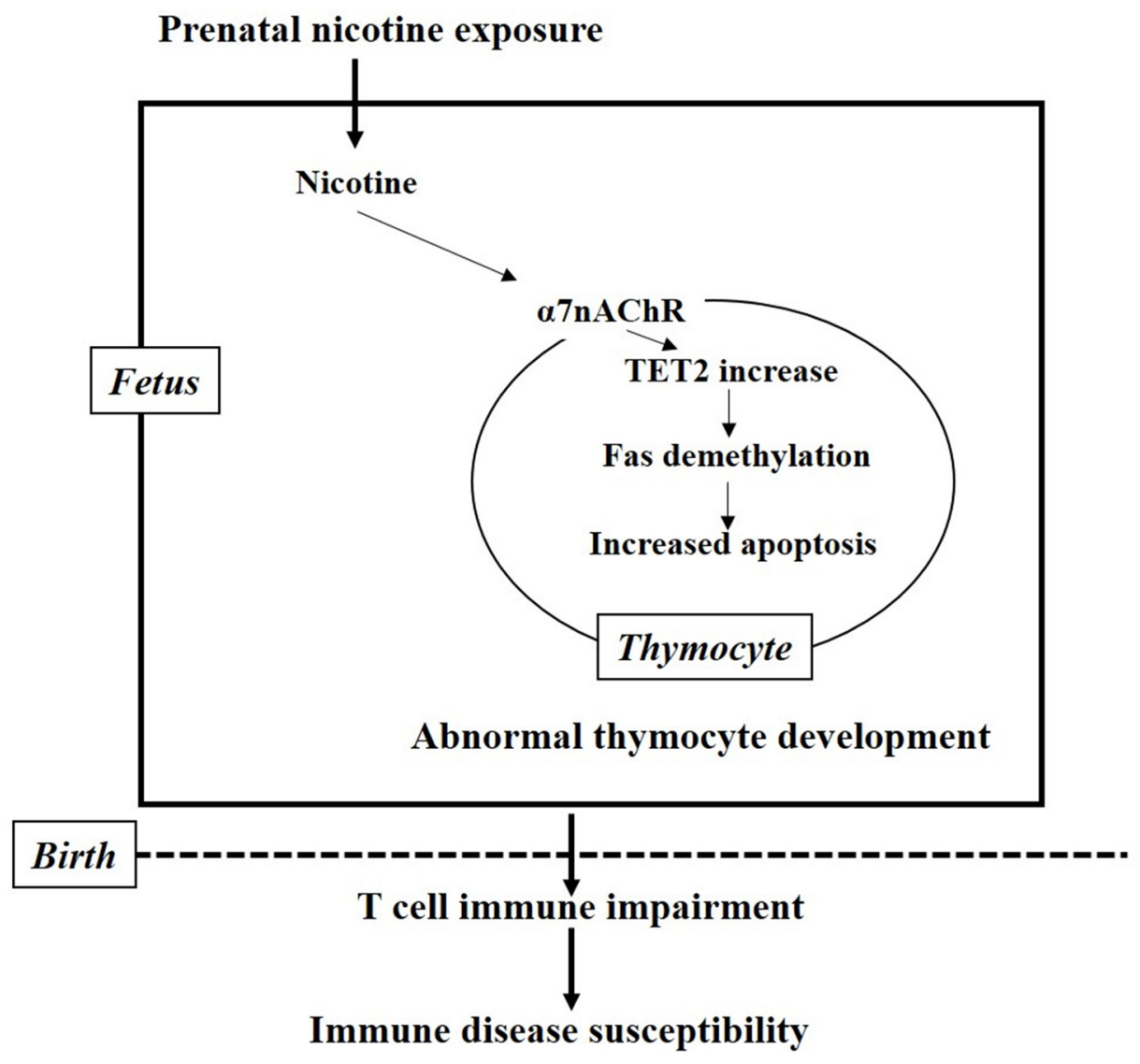

Figure 8: The mechanism hypothesis for the present study. Nicotine activates the $\alpha 7$ nAChR on thymocyte and increases the expression of TET2, which in turn induce the demethylation of the Fas promoter followed by increased Fas expression and upregulated Fas apoptotic pathway in thymocyte. The increased fetal thymocyte apoptosis finally results in immune impairment and susceptibility to immune diseases after birth. 
cytometry staining (FCS) buffer (PBS, 1\% FBS, 0.02\% sodium azide). A cell apoptosis assay was performed using flow cytometry according to the method previously described [34]. Briefly, thymocytes were stained with $100 \mu \mathrm{l}$ of antibody cocktail (FITC-CD3, APC-CD4 and PE-cy7-CD8) in FCS buffer for $30 \mathrm{~min}$ on ice in the dark. After surface staining, the cells were washed and incubated with $100 \mu \mathrm{l}$ of fluorochrome-conjugated Annexin $\mathrm{V}$ at room temperature for $10 \mathrm{~min}$. Then, the cells were washed and resuspended in $200 \mu \mathrm{l}$ of binding buffer. 7-Aminoactinomycin D (7-AAD) was added before being analyzed by flow cytometry. Samples were determined with a BD FCS AriaTM III flow cytometer (BD Biosciences). Flow cytometry data were analyzed and plotted using FlowJo software. For Fas analysis, CD95 expression was also detected.

\section{Measurement of total IgG1, IgG2a antibodies and IL4 in serum on PND49}

The levels of IL-4, total IgG1 and total IgG2a in offspring serum were determined using ELISA kits according to the manufacturer's protocols. The dilution ratio of serum samples for $\operatorname{IgG} 1$ detection was 1:10000, and for $\operatorname{IgG} 2 \mathrm{a}$ was 1:2000. There was no dilution for IL-4 detection.

\section{In vitro experiments}

\section{Thymic primary cell culturing and treatment}

Thymocyte development reaches its peak during adolescence (in mice, 5 weeks), and then increased sex hormones lead to physiological thymus involution and massive thymocyte apoptosis [29]. Therefore, to obtain thymocytes in the best condition and to avoid excessive physiological apoptosis, we obtained primary thymocytes from mice at 3 to 4 weeks to explore the direct effect and mechanisms of nicotine on thymocyte apoptosis. Thymus lobes dissected from infant mice at age 3 weeks were placed on a stainless steel sieve in a 6-well plate in $1 \mathrm{ml}$ of complete RPMI1640 medium (supplemented with 20\% FBS) and were gently dissociated over the screen using the plunger of a $2 \mathrm{~mL}$ syringe. Cells were washed in medium for $5 \mathrm{~min}, 500 \times \mathrm{g}$ at $4^{\circ} \mathrm{C}$ and cultured in complete medium at $37^{\circ} \mathrm{C}$ in $5 \% \mathrm{CO}_{2}$. Cells were synchronized by serum starvation for at least $12 \mathrm{~h}$ before treatment with nicotine for the indicated periods or concentrations. The sample sizes of cells per group were 3-4 for all in vitro experiments. To study the dose-effect and time-effect of nicotine on thymocyte apoptosis, the cells were treated with the different concentrations $(25$, 50 and $100 \mu \mathrm{M}$ ) of nicotine for $48 \mathrm{~h}$ or $50 \mu \mathrm{M}$ of nicotine for $24 \mathrm{~h}, 48 \mathrm{~h}$ and $72 \mathrm{~h}$ (Supplementary Figure 2). To investigate the role of $\alpha 7 \mathrm{nAChR}$ in nicotine-mediated apoptosis, the cells were pretreated with $1 \mu \mathrm{g} / \mathrm{ml}$ of $\alpha$-bungarotoxin, an $\alpha 7 \mathrm{nAChR}$ specific antagonist, $30 \mathrm{~min}$ before nicotine treatment.

\section{SiRNA-TET2 transfection}

To explore the role of TET2 in the DNA methylation of the Fas promoter, TET2 siRNA transfection using Lipofectamine 3000 reagent was performed according to the manufacturer's protocol. Briefly, cells were seeded on 96-well plates at a density of $5 \times 10^{6} / \mathrm{ml}$ and cultured for $24 \mathrm{~h}$ before transfection. The siRNA and Lipofectamine 3000 were diluted in Opti-MEM medium without serum, then the dilution of siRNA and Lipofectamine 3000 were mixed at a ratio of $1: 3 \mathrm{w} / \mathrm{v}$. This mixture was stored at room temperature for $15 \mathrm{~min}$ and added to 96 -well plate by dispensing $100 \mathrm{nM}$ siRNA per well. Cells were harvested for analysis $24 \mathrm{~h}$ after transfection.

\section{Flow cytometry}

For in vitro experiments, the cells were also rinsed with FCS buffer and resuspended at $1 \times 10^{7} \mathrm{cell} / \mathrm{s} / \mathrm{ml}$ in FCS buffer. A cell apoptosis assay was performed as described above. For Fas analysis, CD95 expression was also detected.

\section{Caspase- 3 and caspase-8 activity assay}

The activities of caspase- 3 and caspase- 8 were determined using the Caspase Action kits according to the manufacturer's protocols. Assays were performed on 96-well plates by incubating $10 \mu$ thymocyte lysate per sample in $80 \mu \mathrm{l}$ reaction buffer (1\% NP-40, 20 mM Tris$\mathrm{HCl}$ ( $\mathrm{pH} 7.5), 137 \mathrm{mM}$ Nad and 10\% glycerol) containing $10 \mu \mathrm{l}$ substrate (Ac-DEVD-pNA) $(2 \mathrm{mM})$. The lysates were incubated at $37^{\circ} \mathrm{C}$ for $4 \mathrm{~h}$ and measured with an ELISA reader at an absorbance of $405 \mathrm{~nm}$.

\section{Western blot}

Proteins were obtained by lysis buffer as previously described [69]. Proteins were loaded onto SDS-PAGE gels for electrophoresis and then transferred onto PVDF membranes. After blocking in 5\% fat-free milk in TBST for $1.5 \mathrm{~h}$, the membranes were incubated with primary antibody (anti-a $7 \mathrm{nAChR}$, anti-TET2) at $4^{\circ} \mathrm{C}$ overnight. Subsequently, the membranes were incubated with corresponding HRP-conjugated secondary antibodies at room temperature for $1.5 \mathrm{~h}$. After washing 3 times with TBST (for $10 \mathrm{~min}$ each), bound antibodies were visualized using enhanced chemiluminescence. Glyceraldehyde phosphate dehydrogenase (GAPDH) was used as a loading control.

\section{RNA preparation and $q P C R$}

Total RNA was isolated from the thymocytes using Trizol reagent according to the manufacturer's protocol. The concentration and purity of the isolated RNA were determined by a spectrophotometer, and the concentration of each sample was adjusted to $1 \mu \mathrm{g} / \mu \mathrm{l}$. Single-strand cDNA was prepared using a reverse transcription kit. All primer sequences shown in Supplementary Table 1 were designed by Primer Premier 5.0 from PREMIER Biosoft International (Palo Alto, CA, USA) and queried 
by NCBI BLAST database for homology comparison. PCR assays were performed using a QuantStudio 6 Flex from Applied Biosystems (Foster City, CA, USA) in a total volume of $20 \mu \mathrm{l}$ reaction mixture containing $1 \mu \mathrm{l}$ of cDNA template, $0.4 \mu \mathrm{l}$ of $10 \mu \mathrm{M}$ each primer, $10 \mu \mathrm{l}$ of $2 \times$ Premix Ex Taq, $0.4 \mu \mathrm{l}$ of ROX and $7.8 \mu \mathrm{l}$ of DEPC$\mathrm{H}_{2} \mathrm{O}$. PCR cycling conditions were as follows: $30 \mathrm{~s}$ at $95^{\circ} \mathrm{C}$ for pre-denaturation, $5 \mathrm{~s}$ at $95^{\circ} \mathrm{C}$ for denaturation, and appropriate annealing conditions for each gene (Supplementary Table 1). The ranges of the CT values of GAPDH were 20-22. The ranges of the $\mathrm{Ct}$ values of the other genes were 26-31. The mRNA expression levels were calculated using the $\Delta \Delta \mathrm{Ct}$ method using GAPDH as an internal control. The relative mRNA expression levels were standardized by setting the corresponding gene expression of the control group as 1 .

\section{Genomic DNA extraction and DNA methylation assay based on MassARRAY}

Genomic DNA was isolated from the thymocytes using the TIANamp Genomic DNA Kit, according to the manufacturer's protocol. The quality and quantity were evaluated by a spectrophotometer. Isolated Genomic DNA samples were bisulfite-treated to convert all $\mathrm{C}$ bases that are not methylated to U bases. PCR primers for the Fas gene were designed using Sequenom's EpiDesigner (Sequenom). Two primers were used for PCR amplification (Fas1 and Fas2), which cover the CpG-rich region in the Fas promoter. Primers for Fas1 (-2480 bp -2141 bp) were as follows: forward: 5'- aggaagagagAG TGTGGTTGGTATTGGGTGTTAT-3'; reverse: 5'-cagtaatacgactcactatag ggagaaggctAATTCAACA CATCCACAATTTAACAA-3'. Primers for Fas2 (174 bp $\sim 596$ bp) were as follows: forward: 5'-aggaagagagA AAAGGGAAAATTTTTATTTGTTGTG-3'; reverse: 5'cagtaatacgactcactatagggagaaggctCAATAAATTTTACA AACCTTCTAACCC-3'. The bisulfite-converted DNA was PCR amplified $\left(94^{\circ} \mathrm{C}\right.$ for $4 \mathrm{~min} ; 45$ cycles of $94^{\circ} \mathrm{C}$ for $20 \mathrm{~s}, 60^{\circ} \mathrm{C}$ for $30 \mathrm{~s}$, and $72^{\circ} \mathrm{C}$ for $1 \mathrm{~min} ; 72^{\circ} \mathrm{C}$ for $3 \mathrm{~min}$ ), and then the amplified products were transcribed into RNA fragments using the T7 RNA polymerase (T-cleavage transcription, $37^{\circ} \mathrm{C}$ for $180 \mathrm{~min}$ ). Mass spectra were acquired using a MassARRAY MALDITOF MS (Sequenom). According to the 16 Da molecular weight differences between $\mathrm{CpG}$ and $\mathrm{CpA}$, peak detection and methylation ratio calculations were performed using EpiTyper software (Sequenom).

\section{Statistical analysis}

The sample sizes (n) of animals per group for IL-4, $\mathrm{IgG} 1$, and $\mathrm{IgG} 2 \mathrm{a}$ detection were $8-10$. For the in vivo flow cytometry experiments and all of the in vitro experiments, the sample sizes (n) were 3-4 per group. All measurement data were expressed as the mean $\pm \mathrm{SD}$. The difference between two groups was compared using the $t$-test, and the difference among multiple groups was analyzed with one-way ANOVA. Values of $P<0.05$ were considered statistically significant. Data were analyzed using SPSS 17 (SPSS Science Inc., Chicago, Illinois) and Prism (GraphPad Software, Inc., La Jolla, CA, USA, version 5.0).

\section{Abbreviations}

DN: $\mathrm{CD}^{-} \mathrm{CD}^{-}$double negative thymocytes; Dnmt: DNA methyltransferase; DP: $\mathrm{CD}^{+} \mathrm{CD}^{+}$double positive thymocytes; FBS: fetal bovine serum; FCS: flow cytometry staining; GAPDH: glyceraldehyde phosphate dehydrogenase; GD: gestational day; IL: interleukin; Ig: immunoglobulin; nAChR: nicotinic acetylcholine receptor; PBS: phosphate-buffered saline; PNE: prenatal nicotine exposure; PND: postnatal day; RT-PCR: reversetranscription PCR; SP: single positive thymocytes; $S$. pneumoniae: streptococcus pneumoniae vaccine; TET: tet methylcytosine dioxygenase.

\section{Author contributions}

H.L., S. L., and J.P. designed experiments. H.L., S.L., W.Q., H.Y., X.W., T.C., L.H., and J.P. performed experiments. H.L. and S. L. analyzed data. H.L. and J.P. wrote the paper. All authors read and approved the final manuscript.

\section{CONFLICTS OF INTEREST}

No potential conflicts of interest were disclosed.

\section{FUNDING}

This work was supported by Grants from the National Natural Science Foundation of China (No. 81673215, 81273107), and the Applied Fundamental Research Project of Wuhan (No. 2017060201010199).

\section{REFERENCES}

1. Lisciandro JG, van den Biggelaar AH. Neonatal immune function and inflammatory illnesses in later life: lessons to be learnt from the developing world? Clin Exp Allergy. 2010; 40:1719-31.

2. Suh DI, Chang HY, Lee E, Yang SI, Hong SJ. Prenatal Maternal Distress and Allergic Diseases in Offspring: Review of Evidence and Possible Pathways. Allergy Asthma Immunol Res. 2017; 9:200-11.

3. Hertz-Picciotto I, Park HY, Dostal M, Kocan A, Trnovec T, Sram R. Prenatal exposures to persistent and nonpersistent organic compounds and effects on immune system development. Basic Clin Pharmacol Toxicol. 2008; 102:146-54.

4. McFadden JP, Thyssen JP, Basketter DA, Puangpet P, Kimber I. T helper cell 2 immune skewing in pregnancy/ 
early life: chemical exposure and the development of atopic disease and allergy. Br J Dermatol. 2015; 172:584-91.

5. Dietert RR, Piepenbrink MS. Perinatal immunotoxicity: why adult exposure assessment fails to predict risk. Environ Health Perspect. 2006; 114:477-83.

6. Pozzesi N, Fierabracci A, Liberati AM, Martelli MP, Ayroldi E, Riccardi C, Delfino DV. Role of caspase-8 in thymus function. Cell Death Differ. 2014; 21:226-33.

7. Rodrigues V Jr, Agrelli GS, Leon SC, Silva Teixeira DN, Tostes S Jr, Rocha-Rodrigues DB. Fas/Fas-L expression, apoptosis and low proliferative response are associated with heart failure in patients with chronic Chagas' disease. Microbes Infect. 2008; 10:29-37.

8. Fenaux JB, Gogal RM Jr, Ahmed SA. Diethylstilbestrol exposure during fetal development affects thymus: studies in fourteen-month-old mice. J Reprod Immunol. 2004; 64:75-90.

9. Gruslin A, Cesta CE, Bell M, Qing Q, Petre MA, Holloway AC. Effect of nicotine exposure during pregnancy and lactation on maternal, fetal, and postnatal rat IGF-II profile. Reprod Sci. 2009; 16:875-82.

10. Bruin JE, Gerstein HC, Holloway AC. Long-term consequences of fetal and neonatal nicotine exposure: a critical review. Toxicol Sci. 2010; 116:364-74.

11. Jeppesen DL, Hasselbalch H, Nielsen SD, Sorensen TU, Ersboll AK, Valerius NH, Heilmann C. Thymic size in preterm neonates: a sonographic study. Acta Paediatr. 2003; 92:817-22.

12. Hanson ML, Holaskova I, Elliott M, Brundage KM, Schafer R, Barnett JB. Prenatal cadmium exposure alters postnatal immune cell development and function. Toxicol Appl Pharmacol. 2012; 261:196-203.

13. Yildiz D. Nicotine, its metabolism and an overview of its biological effects. Toxicon. 2004; 43:619-32.

14. Lambers DS, Clark KE. The maternal and fetal physiologic effects of nicotine. Semin Perinatol. 1996; 20:115-26.

15. Zeidler R, Albermann K, Lang S. Nicotine and apoptosis. Apoptosis. 2007; 12:1927-43.

16. Middlebrook AJ, Martina C, Chang Y, Lukas RJ, DeLuca D. Effects of nicotine exposure on T cell development in fetal thymus organ culture: arrest of $\mathrm{T}$ cell maturation. $\mathrm{J}$ Immunol. 2002; 169:2915-24.

17. Itier V, Bertrand D. Neuronal nicotinic receptors: from protein structure to function. FEBS Lett. 2001; 504:118-25.

18. Guerra-Alvarez M, Moreno-Ortega AJ, Navarro E, Fernandez-Morales JC, Egea J, Lopez MG, Cano-Abad MF. Positive allosteric modulation of alpha-7 nicotinic receptors promotes cell death by inducing $\mathrm{Ca}(2+)$ release from the endoplasmic reticulum. J Neurochem. 2015; 133:309-19.

19. Vivekanandarajah A, Chan YL, Chen H, Machaalani R. Prenatal cigarette smoke exposure effects on apoptotic and nicotinic acetylcholine receptor expression in the infant mouse brainstem. Neurotoxicology. 2016; 53:53-63.

20. Barker DJ. In utero programming of chronic disease. Clin Sci (Lond). 1998; 95:115-28.
21. Martino DJ, Prescott SL. Silent mysteries: epigenetic paradigms could hold the key to conquering the epidemic of allergy and immune disease. Allergy. 2010; 65:7-15.

22. Castellano R, Vire B, Pion M, Quivy V, Olive D, Hirsch I, Van Lint C, Collette Y. Active transcription of the human FASL/ CD95L/TNFSF6 promoter region in T lymphocytes involves chromatin remodeling: role of DNA methylation and protein acetylation suggest distinct mechanisms of transcriptional repression. J Biol Chem. 2006; 281:14719-28.

23. Mudd AT, Alexander LS, Johnson SK, Getty CM, Malysheva OV, Caudill MA, Dilger RN. Perinatal Dietary Choline Deficiency in Sows Influences Concentrations of Choline Metabolites, Fatty Acids, and Amino Acids in Milk throughout Lactation. J Nutr. 2016; 146:2216-23.

24. Yan YE, Liu L, Wang JF, Liu F, Li XH, Qin HQ, Wang H. Prenatal nicotinic exposure suppresses fetal adrenal steroidogenesis via steroidogenic factor 1 (SF-1) deacetylation. Toxicol Appl Pharmacol. 2014; 277:231-41.

25. Wu DM, He Z, Chen T, Liu Y, Ma LP, Ping J. DNA hypermethylation of acetoacetyl-CoA synthetase contributes to inhibited cholesterol supply and steroidogenesis in fetal rat adrenals under prenatal nicotine exposure. Toxicology. 2016; 340:43-52.

26. Wang T, Chen M, Liu L, Cheng H, Yan YE, Feng YH, Wang $\mathrm{H}$. Nicotine induced $\mathrm{CpG}$ methylation of Pax6 binding motif in StAR promoter reduces the gene expression and cortisol production. Toxicol Appl Pharmacol. 2011; 257:328-37.

27. Tsaprouni LG, Yang TP, Bell J, Dick KJ, Kanoni S, Nisbet J, Vinuela A, Grundberg E, Nelson CP, Meduri E, Buil A, Cambien F, Hengstenberg C, et al. Cigarette smoking reduces DNA methylation levels at multiple genomic loci but the effect is partially reversible upon cessation. Epigenetics. 2014; 9:1382-96.

28. Singh SP, Mishra NC, Rir-Sima-Ah J, Campen M, Kurup V, Razani-Boroujerdi S, Sopori ML. Maternal exposure to secondhand cigarette smoke primes the lung for induction of phosphodiesterase-4D5 isozyme and exacerbated Th2 responses: rolipram attenuates the airway hyperreactivity and muscarinic receptor expression but not lung inflammation and atopy. J Immunol. 2009; 183:2115-21.

29. Gordon J, Manley NR. Mechanisms of thymus organogenesis and morphogenesis. Development. 2011; 138:3865-78.

30. Ozturk F, Sheldon E, Sharma J, Canturk KM, Otu HH, Nawshad A. Nicotine Exposure During Pregnancy Results in Persistent Midline Epithelial Seam With Improper Palatal Fusion. Nicotine Tob Res. 2016; 18:604-12.

31. Tahajjodi SS, Amerion M, Mahdavi Shahri N, Jalali M, Nikravesh MR. The effect of maternal nicotine on basement membrane collagen IV of brain microvessels changes in neonatal Balb/C mice. Iran J Reprod Med. 2014; 12:275-80.

32. Mahdi Shariati K, Mohammad Reza N, Mehdi J, Alireza F, Mojtaba S, Bideskan AE. Effects of maternal nicotine exposure on expression of laminin alpha 5 in lung tissue of newborn. Pak J Biol Sci. 2012; 15:1168-75. 
33. Benowitz NL, Zevin S, Jacob P 3rd. Suppression of nicotine intake during ad libitum cigarette smoking by high-dose transdermal nicotine. J Pharmacol Exp Ther. 1998; 287:958-62.

34. Chen T, Yan YE, Liu S, Liu HX, Yan HY, Hou LF, Qu W, Ping J. Increased Fetal Thymocytes Apoptosis Contributes to Prenatal Nicotine Exposure-induced Th1/Th2 Imbalance in Male Offspring Mice. Sci Rep. 2016; 6:39013. https:// doi.org/10.1038/srep39013.

35. Rossant J. Lineage development and polar asymmetries in the peri-implantation mouse blastocyst. Semin Cell Dev Biol. 2004; 15:573-81.

36. Zhang $\mathrm{C}, \mathrm{Xu} \mathrm{D}$, Luo $\mathrm{H}$, Lu J, Liu L, Ping J, Wang H. Prenatal xenobiotic exposure and intrauterine hypothalamus-pituitary-adrenal axis programming alteration. Toxicology. 2014; 325:74-84.

37. Papaioannou KA, Markopoulou CE, Gioni V, Mamalis AA, Vayouraki HN, Kletsas D, Vrotsos IA. Attachment and proliferation of human osteoblast-like cells on guided bone regeneration (GBR) membranes in the absence or presence of nicotine: an in vitro study. Int J Oral Maxillofac Implants. 2011; 26:509-19.

38. Laytragoon-Lewin N, Bahram F, Rutqvist LE, Turesson I, Lewin F. Direct effects of pure nicotine, cigarette smoke extract, Swedish-type smokeless tobacco (Snus) extract and ethanol on human normal endothelial cells and fibroblasts. Anticancer Res. 2011; 31:1527-34.

39. Naha N, Lee HY, Hwang JS, Bahk JY, Park MS, Lee $\mathrm{SY}$, Kim SH, Kim MO. Nicotine tolerance to PC12 cell line: acute and chronic exposures modulate dopamine D2 receptor and tyrosine hydroxylase expression. Neurol Res. 2009; 31:289-99. https://doi. org/10.1179/174313209X382403.

40. Klettner AK, Doths J, Roider J. Nicotine reduces VEGFsecretion and phagocytotic activity in porcine RPE. Graefes Arch Clin Exp Ophthalmol. 2012; 250:33-8. https:/doi. org/10.1007/s00417-011-1776-8.

41. Singh SP, Gundavarapu S, Pena-Philippides JC, Rir-Simaah J, Mishra NC, Wilder JA, Langley RJ, Smith KR, Sopori ML. Prenatal secondhand cigarette smoke promotes Th2 polarization and impairs goblet cell differentiation and airway mucus formation. J Immunol. 2011; 187:4542-52

42. Hanson ML, Brundage KM, Schafer R, Tou JC, Barnett JB. Prenatal cadmium exposure dysregulates sonic hedgehog and Wnt/beta-catenin signaling in the thymus resulting in altered thymocyte development. Toxicol Appl Pharmacol. 2010; 242:136-45. https://doi.org/10.1016/j. taap.2009.09.023.

43. Mohsenzadeh Y, Rahmani A, Cheraghi J, Pyrani M, Asadollahi K. Prenatal exposure to nicotine in pregnant rat increased inflammatory marker in newborn rat. Mediators Inflamm. 2014; 2014:274048.

44. Abbas AK, Murphy KM, Sher A. Functional diversity of helper T lymphocytes. Nature. 1996; 383:787-93.
45. Vadesilho CF, Ferreira DM, Moreno AT, Chavez-Olortegui C, Machado de Avila RA, Oliveira ML, Ho PL, Miyaji EN. Characterization of the antibody response elicited by immunization with pneumococcal surface protein A (PspA) as recombinant protein or DNA vaccine and analysis of protection against an intranasal lethal challenge with Streptococcus pneumoniae. Microb Pathog. 2012; 53:243-9.

46. Miller JF. The discovery of thymus function and of thymusderived lymphocytes. Immunol Rev. 2002; 185:7-14.

47. Singh NP, Abbas IK, Menard M, Singh UP, Zhang J, Nagarkatti P, Nagarkatti M. Exposure to diethylstilbestrol during pregnancy modulates microRNA expression profile in mothers and fetuses reflecting oncogenic and immunological changes. Mol Pharmacol. 2015; 87:842-54.

48. van den Brandt J, Luhder F, McPherson KG, de Graaf KL, Tischner D, Wiehr S, Herrmann T, Weissert R, Gold R, Reichardt HM. Enhanced glucocorticoid receptor signaling in $\mathrm{T}$ cells impacts thymocyte apoptosis and adaptive immune responses. Am J Pathol. 2007; 170:1041-53.

49. Singh NP, Singh UP, Guan H, Nagarkatti P, Nagarkatti M. Prenatal exposure to TCDD triggers significant modulation of microRNA expression profile in the thymus that affects consequent gene expression. PLoS One. 2012; 7:e45054.

50. Liu HX, Jiang A, Chen T, Qu W, Yan HY, Ping J. Reproductive Toxicity of T Cells in Early Life: Abnormal Immune Development and Postnatal Diseases. Curr Drug Targets. 2017; 18:1132-41.

51. Harada Y, Tanaka S, Motomura Y, Harada Y, Ohno S, Ohno S, Yanagi Y, Inoue H, Kubo M. The 3' enhancer CNS2 is a critical regulator of interleukin-4-mediated humoral immunity in follicular helper $\mathrm{T}$ cells. Immunity. 2012; 36:188-200.

52. Berger F, Gage FH, Vijayaraghavan S. Nicotinic receptorinduced apoptotic cell death of hippocampal progenitor cells. J Neurosci. 1998; 18:6871-81.

53. West KA, Brognard J, Clark AS, Linnoila IR, Yang X, Swain SM, Harris C, Belinsky S, Dennis PA. Rapid Akt activation by nicotine and a tobacco carcinogen modulates the phenotype of normal human airway epithelial cells. J Clin Invest. 2003; 111:81-90.

54. Wang YY, Liu Y, Ni XY, Bai ZH, Chen QY, Zhang Y, Gao FG. Nicotine promotes cell proliferation and induces resistance to cisplatin by alpha7 nicotinic acetylcholine receptormediated activation in Raw264.7 and El4 cells. Oncol Rep. 2014; 31:1480-8.

55. Slotkin TA, Orband-Miller L, Queen KL, Whitmore WL, Seidler FJ. Effects of prenatal nicotine exposure on biochemical development of rat brain regions: maternal drug infusions via osmotic minipumps. J Pharmacol Exp Ther. 1987; 240:602-11.

56. Thaler R, Karlic H, Spitzer S, Klaushofer K, Varga F. Extracellular matrix suppresses expression of the apoptosis mediator Fas by epigenetic DNA methylation. Apoptosis. $2010 ; 15: 728-37$. 
57. Gazin C, Wajapeyee N, Gobeil S, Virbasius CM, Green MR. An elaborate pathway required for Ras-mediated epigenetic silencing. Nature. 2007; 449:1073-7.

58. van der Wijst MG, Venkiteswaran M, Chen H, Xu GL, Plosch T, Rots MG. Local chromatin microenvironment determines DNMT activity: from DNA methyltransferase to DNA demethylase or DNA dehydroxymethylase. Epigenetics. 2015; 10:671-6.

59. Yang R, Qu C, Zhou Y, Konkel JE, Shi S, Liu Y, Chen C, Liu S, Liu D, Chen Y, Zandi E, Chen W, Zhou Y, et al. Hydrogen Sulfide Promotes Tet1- and Tet2-Mediated Foxp3 Demethylation to Drive Regulatory T Cell Differentiation and Maintain Immune Homeostasis. Immunity. 2015; 43:251-63. https://doi.org/10.1016/j.immuni.2015.07.017.

60. Kim SG, Jong HS, Kim TY, Lee JW, Kim NK, Hong $\mathrm{SH}$, Bang YJ. Transforming growth factor-beta 1 induces apoptosis through Fas ligand-independent activation of the Fas death pathway in human gastric SNU-620 carcinoma cells. Mol Biol Cell. 2004; 15:420-34. https://doi. org/10.1091/mbc.E03-04-0201.

61. Nair VS, Oh KI. Down-regulation of Tet2 prevents TSDR demethylation in IL2 deficient regulatory T cells. Biochem Biophys Res Commun. 2014; 450:918-24.

62. Geng Y, Savage SM, Razani-Boroujerdi S, Sopori ML. Effects of nicotine on the immune response. II. Chronic nicotine treatment induces T cell anergy. J Immunol. 1996; 156:2384-90.

63. Webb LV, Ley SC, Seddon B. TNF activation of NF-kappaB is essential for development of single-positive thymocytes. J Exp Med. 2016; 213:1399-407. https://doi.org/10.1084/ jem.20151604.

64. Tsagaratou A, Trompouki E, Grammenoudi S, Kontoyiannis DL, Mosialos G. Thymocyte-specific truncation of the deubiquitinating domain of CYLD impairs positive selection in a NF-kappaB essential modulator-dependent manner. J Immunol. 2010; 185:2032-43. https://doi. org/10.4049/jimmunol.0903919.

65. Cull AH, Snetsinger B, Buckstein R, Wells RA, Rauh MJ. Tet2 restrains inflammatory gene expression in macrophages. Exp Hematol. 2017 Aug 18. https://doi. org/10.1016/j.exphem.2017.08.001. [Epub ahead of print].

66. Chernyavsky AI, Arredondo J, Galitovskiy V, Qian J, Grando SA. Upregulation of nuclear factor-kappaB expression by SLURP-1 is mediated by alpha7-nicotinic acetylcholine receptor and involves both ionic events and activation of protein kinases. Am J Physiol Cell Physiol. 2010; 299:C903-11. https://doi.org/10.1152/ ajpcell.00216.2010.

67. Li Q, Zhou XD, Kolosov VP, Perelman JM. Nicotine reduces TNF-alpha expression through a alpha7 $\mathrm{nAChR} /$ MyD88/NF-kB pathway in HBE16 airway epithelial cells. Cell Physiol Biochem. 2011; 27:605-12. https://doi. org/10.1159/000329982.

68. Wu L, Zhou Y, Zhou Z, Liu Y, Bai Y, Xing X, Wang X. Nicotine induces the production of IL-1beta and IL-8 via the alpha7 nAChR/NF-kappaB pathway in human periodontal ligament cells: an in vitro study. Cell Physiol Biochem. 2014; 34:423-31. https://doi.org/10.1159/000363011.

69. Ping J, Gao AM, Qin HQ, Wei XN, Bai J, Liu L, Li XH, Li RW, Ao Y, Wang H. Indole-3-carbinol enhances the resolution of rat liver fibrosis and stimulates hepatic stellate cell apoptosis by blocking the inhibitor of kappaB kinase alpha/inhibitor of kappaB-alpha/nuclear factor-kappaB pathway. J Pharmacol Exp Ther. 2011; 339:694-703. 